\title{
Relationship of the Big Five Personality Traits and Risk Aversion with Investment Intention of Individual Investors
}

\author{
Danish SARWAR ${ }^{1}$, Bilal SARWAR ${ }^{2}$, Muhammad Asif RAZ ${ }^{3}$, Hadi Hassan KHAN ${ }^{4}$, Noor MUHAMMAD, \\ Usman AZHAR ${ }^{6}$, Nadeem uz ZAMAN ${ }^{7}$, Mumraiz Khan KASI ${ }^{8}$
}

Received: September 10, 2020 Revised: November 02, 2020 Accepted: November 16, 2020

\begin{abstract}
This empirical research is aimed at testing the relationship of the big five personality traits namely openness to experience, extraversion, consciousness, agreeableness, neuroticism, and risk aversion with the investment intention of individual investors belonging to Balochistan, Pakistan. The primary data is collected through a self-administered questionnaire (a structured form that consists of a series of closed-ended and open-ended questions) from a sample of 397 active individual investors belonging to different districts of the province. The data is empirically analyzed by applying the Partial Least Square (PLS) path modeling technique by using the estimation package available in Smart-PLS. The findings of this study suggest that all the variables are statistically significant with investors' investment intention with risk aversion as the strongest predictor. Moreover, openness to experience, extraversion, consciousness, agreeableness, and risk are significantly and positively related to an investor's investment intention, whereas neuroticism is negatively related to an investor's investment intention. The results extended by this study can be used by financial planners and investment bankers to channelize the available financial resources in diversified portfolios. The results will help financial planners to make available diverse investment alternatives for investors in Balochistan, thus catering to their unique needs. Academia must offer courses on contemporary finance paradigm based on behavioral finance to enable future business graduates to make wise financial decisions.
\end{abstract}

Keywords: Disjoint Two-Stage Analysis, Investment Intention, Personality Traits, PLS Path Modeling

JEL Classification Code: G41, C83, C88

${ }^{1}$ First Author. Department of Management Sciences, Faculty of Management Sciences, Balochistan University of Information Technology Engineering \& Management Sciences, Quetta, Balochistan, Pakistan. Email: danish.sarwar@buitms.edu.pk

${ }^{2}$ Corresponding Author. Assistant Professor, Department of Management Sciences, Faculty of Management Sciences, Balochistan University of Information Technology Engineering \& Management Sciences, Pakistan [Postal Address: Jinnah Town, Samungli Road, Quetta, Balochistan, 87200, Pakistan]

Email: bilal.sarwar@buitms.edu.pk

${ }^{3}$ Assistant Professor, Department of Management Sciences, Faculty of Management Sciences, Balochistan University of Information Technology Engineering \& Management Sciences, Quetta, Balochistan, Pakistan. Email: asif.raz@buitms.edu.pk ${ }^{4}$ Assistant Professor, Department of Management Sciences, Faculty of Management Sciences, Balochistan University of Information Technology Engineering \& Management Sciences, Quetta, Balochistan, Pakistan. Email: hadihassankhan@gmail.com

${ }^{5}$ Associate Professor, Department of Management Sciences, Faculty of Management Sciences, Balochistan University of
Information Technology Engineering \& Management Sciences, Quetta, Balochistan, Pakistan.

Email: noor.muhammad@buitms.edu.pk

${ }^{6}$ Associate Professor, Department of Economics, Faculty of Management Sciences, Balochistan University of Information Technology Engineering \& Management Sciences, Quetta, Balochistan, Pakistan. Email: usman@buitms.edu.pk

${ }^{7}$ Assistant Professor, Department of Management Sciences, Faculty of Management Sciences, Balochistan University of Information Technology Engineering \& Management Sciences, Quetta, Balochistan, Pakistan. Email: nadeem.zaman@buitms.edu.pk

${ }^{8}$ Associate Professor, Department of Computer Science, Faculty of Information and Communication Technology, Balochistan University of Information Technology Engineering \& Management Sciences, Quetta, Balochistan, Pakistan.

Email: mumraiz.kasi@buitms.edu.pk

() Copyright: The Author(s)

This is an Open Access article distributed under the terms of the Creative Commons Attribution Non-Commercial License (https://creativecommons.org/licenses/by-nc/4.0/) which permits unrestricted non-commercial use, distribution, and reproduction in any medium, provided the original work is properly cited. 


\section{Introduction}

Balochistan is the largest province of Pakistan (areawise) but less developed in comparison to other provinces of the country. There are limited investment opportunities available to investors in the province due to the limited access to the stock market, industries, and investment options. Real estate is the most preferred choice of investment as well as investing with the Directorate of National Savings to receive a guaranteed return with minimum risk. The current economic growth as a result of globalization has uplifted the resources of families and has simultaneously framed numerous investment prospects which significantly differ with regard to investment horizon as well as in risk-return (Pellinen et., 2011).

Traditional finance theories consider the postulation of rationality, profit maximization, and effect market. Traditional financial paradigm grounded on the postulation that investors are rational when they face ambiguity and uncertainty in decision-making, used cognitive biases to makes decisions (Nga \& Ken Yien, 2013). The traditional financial paradigm is opposed by behavioral finance which has evolved as a new finance paradigm which states that the investors' investment decisions are influenced by personal and situational factors.

Behavioral finance proposes that a blend of affective and cognitive dimensions are involved in human decision making (Olsen \& Cox, 2001). Investors' insight regarding his/her financial decision-making abilities is affected by personality traits, personal values, emotions, and society. Empirical studies have proven that factors such as personality traits, personal values, emotions, and society are more significant in comparison to the movements in share price and economic conditions (Shiller, 2002; Smith \& Harvey, 2011).

Psychographic conditions play a significant part in determining the investment behavior of people and inseparable risks are involved in their investment decisions. An individual's understanding of risk depends on different variables; most important is the personality traits that individuals possess. Besides, every individual is different from each other; therefore, they have diverse financial goals. The decisions investors make regarding their financial goals are influenced by their personality and rationality; therefore, it is pertinent for financial planners to understand these traits of investors. Furthermore, the connection between investment intentions and personality traits will assist the financial planners in modifying products along with services to suit their potential client's desires (DeBondt et al., 2010).

Financial decision-making becomes difficult if investment alternatives are scarce as is the case in Balochistan where current and prospective investors have limited investment options, while investment decision is the most important in financial management. Compared to other provinces of Pakistan, Balochistan lacks the facility of a stock exchange, limited opportunities in the tourism industry, and the absence of a dry port. The recommended investment areas for Balochistan are limited to real estate investments, livestock, and agriculture. Therefore, this study aims to test the relationship of the five-factor theory (openness to experience, extraversion, consciousness, agreeableness, and neuroticism) and risk aversion with the investment intention of individual investors in Balochistan.

The current empirical research contributes to contemporary literature concerning the investment intention of current and prospective investors. This is the first attempt to investigate the determinants significant in an investor's behavior concerning their investment intention. Furthermore, this study applied the PLS path modeling technique which is widely acknowledged and applied in the study of social sciences (Hair Jr, Ringle, \& Sarstedt, 2011; Hair Jr et al., 2012; Kura, 2016; Kura, Shamsudin, \& Chauhan, 2015; Roldan \& Sanchez-Franco, 2012).

\section{Literature Review}

Financial decision making is an outcome of an individual's intention to invest and is largely influenced by an individual's personality and their inclination towards financial risk. The investment horizon is the term used to describe the total length of time that an investor expects to hold an investment. The intentions to invest can be categorized as short-term or long-term subject to the duration of the investment horizon. Short-term investment intention refers to an individual having a short-term investment horizon for investment to meet the need which may arise soon. Long-term investment intention refers to an individual having a long-term time investment horizon for investment to meet the need which may arise in the distant future.

This study is underpinned by the big five personality theory which is a hierarchical model of personality traits that are categorized into five factors (known as the 'big five') that were derived empirically (Costa, McCrae, \& Holland, 1984; Digman, 1990). Earlier, trait theorists attempted to discover and define several personality traits that existed. Allport (1937) suggested 4000 personality traits and Cattell (1943) listed 16 personality traits. However, these theories were criticized for being too complicated and the five-factor theory that emerged serves as building blocks of personality traits and describes essential traits.

The five-factor theory is one of the dominant approaches to represent human personality traits. For many years, the theory is being developed, beginning with the work of Fiske (1949), later several personality theorists had worked on traits' development (McCrae \& Costa, 1987). The five-factor theory is a theory of personality traits that identifies five distinct factors that 
are also referred to as OCEAN (Openness to Experience, Conscientiousness, Extraversion, Agreeableness, and Neuroticism). The traits represent a range of two extremes such as; extraversion represents two extremes, extroverts, and introverts. This model has been applied extensively by researchers in diverse contexts to study individual differences, for example, in organizations (Bozionelos, 2004; Erdheim, Wang, \& Zickar, 2006; Scott \& Colquitt, 2007; Udin \& Yuniawan, 2020), in educational institutions (Busato et al., 1998; Komarraju \& Karau, 2005; Vorkapic, 2012), in clinical studies (Muris, 2006; Nigg et al., 2002), and leisure experiences (Han, 2020). Nguyen and Nguyen (2020) analyzed the impact of operating cash flow on individual investor's decision making for listed firms on Vietnam's stock market exchange by applying a T-test.

Numerous studies have been carried out on diverse traits of personality, nevertheless, OCEAN traits developed by Allport (1937) is the best. Personality traits comprise motivational, cognitive, and emotional characteristics that influence several decisions of individuals (Dolan et al., 2012). One of the decisions is, the financial decision (Crysel, Crosier, \& Webster, 2013), and an investor's personality is related to investment choices and outcomes. (Durand, Newby, \& Sanghani, 2008).

\subsection{Variables and Hypotheses Development}

\subsubsection{Extraversion and Investment Intention}

McCrae and Costa Jr (1997) and Leary, Reilly, and Brown (2009) defined an extrovert as a person who is active, optimistic, excitement seeking and socializes in big crowds. "Extraversion deliberate only positive information, which influences their assessment of the probability of success and instigated overconfidence in financial decision making" (Pan \& Statman, 2013). Mayfield, Perdue, and Wooten (2008) concluded that extraversion often creates a trade-off and tends to capitalize on the money more in the stock market. Durand et al. (2008) revealed that people with a greater tendency towards extraversion are risk-takers and eventually they attain higher returns. Brown and Taylor (2014) empirically examined the relationship of personality traits of households and their financial decision making and that "extraversion is connected with financial assets and unsecured debts".

$\boldsymbol{H}_{i}:$ Extraversion has a positive relationship with an investor's decision making.

\subsubsection{Openness to Experience and Investment Intention}

As defined by Martins (2002), individuals with an attribute of openness to experience are broad-minded, resourceful, and creative. They have an appeal towards new thoughts, aesthetics, and novelty (Gunkel et al., 2010). Mayfield et al. (2008) directed a study among business school undergraduates and revealed that extraversion trade frequently and tend to invest more money in the stock market. "Openness in individuals promotes greater willingness to embrace unconventional rules of thumb prescribed in financial decision making". Investors possessing this trait have a positive association with risk tolerance and prefer investing in stock (Nga \& Ken Yien, 2013). Nandan and Saurabh (2016) described that investors having the "openness to experience" trait tend to take a higher risk than their counterparts.

$\boldsymbol{H}_{2}:$ Openness to experience and investment intention are positively related.

\subsubsection{Agreeableness and Investment Intention}

Agreeableness refers to cooperation, helpfulness, personal warmth, altruism, and sympathy toward others (Mayfield et al., 2008). According to Costa Jr and McCrae (1992), agreeable individuals rely on the financial analyst's judgment and feel hard to make personal financial decisions. Agreeable persons tend to avoid conflicts with others and positively consider the information provided by others without any critical assessment (McCrae \& Costa Jr, 1997).

$\boldsymbol{H}_{3}:$ Agreeableness is positively related to an investor's investment intention.

\subsubsection{Conscientiousness and Investment Intention}

Conscientiousness individuals possessing are punctual, persistent, determined, reliable, and well-organized and are not high risk-takers (Mayfield et al., 2008). Conscientiousness investors avoid depending on misconceptions and sensibly make their investment decisions. Gunkel et al. (2010) stated that "conscientious individuals are actively involved in decision making". Conscientious investors do not rely on delusions and prudently make their investment decisions. This ability makes them more particular about the choice of investment and risk tolerance (Sadi et al., 2011). Durand et al. (2013) stated that individuals with conscience personality have a positive relationship with their trading behavior.

$\boldsymbol{H}_{4}:$ Conscientiousness and investment intention of investors are positively related.

\subsubsection{Neuroticism and Investment Intention}

Neurotic people lack conceptual understanding, critical thinking, cognitive abilities, and analytical skills. 
These shortcomings make neurotic individuals anxious and afraid while taking risky decisions (McCrae \& Costa Jr, 1997; Young et al., 2012). Neurotic investors avoid indecision, are hostile towards risk, and avoid debt securities and foreign equities. As such, neurotic individuals approve portfolios with a low-risk appetite (Gambetti \& Giusberti, 2012). Moreover, Niszczota (2014) found that neurotic individuals avoid investment in foreign securities and avoid uncertainty. Pak and Mahmood (2015) stated that neuroticism has a negative relation to risky behavior.

$\boldsymbol{H}_{5}:$ Neuroticism is negatively related to an investor's investment intention.

\subsubsection{Risk Aversion and Investment Intention}

Risk is well-thought-out as a significant aspect of investment behavior (Kiev, 2003). According to Grable and Lytton (2003), investors with a low-risk attitude invest not only in saving accounts but also prefer holding cash and investment in bonds. Likewise, those with a high-risk attitude choose trading more in derivatives and investments in stocks, contrary to low-risk ones (Wood \& Zaichkowsky, 2004). According to Fellner and Maciejovsky (2007) "Individuals risk behavior determine their investment style". Yet, many aspects influence an individual's risk behavior such as their past experiences (Hunter \& Kemp, 2004), financial knowledge (Young et al., 2012), market volatility (Diacon, 2004), emotions (Grable \& Lytton, 2003), personal traits (Corter \& Chen, 2006), and love for money (Tang, 2007).

$\boldsymbol{H}_{6}$ : The investor's risk aversion is significantly related to an investor's investment intention.

\section{Research Methodology}

The population of the study includes the current and prospective investors from all districts of Balochistan. The sampling frame consisted of literate individuals in government jobs, private jobs, and businessmen, categorized as young adults, middle-aged, and old-aged investors. The Drop-off and Pick-up (DOPU) self-administered method was used to get responses from the participants because it increases the response rate (Riley \& Kiger, 2002). The questionnaires were distributed to the participants and were collected when it was completed.

The sample size for the study was 397 which is greater than the minimum sample size of 254 respondents derived from G-power used for statistical tests as a power analysis program and which is used in social and behavioral research
(Erdfelder, Faul, \& Buchner, 1996). In the present study, the minimum sample size was calculated by taking the effect size $\left(f^{2}\right)$ as 0.1 , probability of type-I $(\alpha)$ error as 0.05 , and power as 0.99 which gives the minimum sample size of 254 .

The construct of long terms investment intention (5-items) and the predictors of the study namely, extraversion (4-items), openness to experience (5-items), agreeableness (4-items), conscientiousness (5-items), neuroticism (5-items), and risk aversion (4-items) was measured using a five-point Likert scale in which responders specify their level of agreement to a statement in 5 points: (1) strongly disagree (2) disagree (3) neither agree nor disagree (4) agree (5) strongly agree (Mayfield et al., 2008). The theoretical model was tested by applying the PLS path modeling in the current empirical work using SmartPLS 3 (Ringle, Wende, \& Becker, 2015). The higher-order construct was measured by applying the disjoint two-stage approach (Sarstedt et al., 2019).

\section{Results and Discussion}

The questionnaires with missing data were excluded from the analysis, hence no missing value issue was encountered by the researcher. While data screening, the responses were detected as outliers by the software, wherein, the condition of value outside three standard deviations (30) was dropped from the analysis.

\subsection{PLS Analysis}

PLS path modeling technique is widely acknowledged and applied in the study of social sciences (Hair Jr et al., 2011, 2012; Kura, 2016; Kura et al., 2015; Roldán \& Sanchez-Franco, 2012). The primary aim of this empirical study was to predict the individual investor's intention to invest (dependent variable). For this, the researcher found PLS path modeling to be the most suitable analysis technique (Hair Jr et al., 2011). This empirical research evaluated and reported PLS-SEM results based on the measurement model (Table 1) and the structural model (Table 3) assessment (Hair Jr et al., 2010, 2016; Henseler, Ringle, \& Sinkovics, 2009).

\subsubsection{Assessment of the Measurement Model}

Researchers use the measurement model assessment by calculating the loading of every single item, Cronbach's Alpha, content validity, convergent validity, and finally the discriminant validity (Hair Jr et al., 2010, 2016; Henseler et al., 2009). The consistency of a questionnaire is measured by reliability analysis (Field, 2009). The assessment of individual items can be evaluated from indicator reliability. The reliability of each latent variable is examined by its internal consistency. 
Table 1: Measurement Model

\begin{tabular}{|c|c|c|c|c|c|c|c|}
\hline Variables & Loadings & CR & AVE & Variables & Loadings & CR & AVE \\
\hline \multicolumn{8}{|c|}{ First-Order Measurement Model } \\
\hline $\begin{array}{l}\text { Long Term Investment } \\
\text { Intention }\end{array}$ & & 0.904 & 0.656 & & & & \\
\hline LT1 & 0.874 & & & Extraversion & & 0.824 & 0.551 \\
\hline LT2 & 0.778 & & & EXTRA1 & 0.445 & & \\
\hline LT3 & 0.838 & & & EXTRA 2 & 0.768 & & \\
\hline LT4 & 0.863 & & & EXTRA 3 & 0.855 & & \\
\hline LT5 & 0.679 & & & EXTRA 4 & 0.827 & & \\
\hline $\begin{array}{l}\text { Short Term Investment } \\
\text { Intention }\end{array}$ & & 0.874 & 0.582 & Neuroticism & & 0.882 & 0.599 \\
\hline ST1 & 0.696 & & & NEU1 & 0.747 & & \\
\hline ST2 & 0.691 & & & NEU 2 & 0.760 & & \\
\hline ST3 & 0.787 & & & NEU 3 & 0.796 & & \\
\hline ST4 & 0.814 & & & NEU 4 & 0.826 & & \\
\hline ST5 & 0.816 & & & NEU 5 & 0.738 & & \\
\hline Agreeableness & & 0.917 & 0.734 & Openness & & 0.932 & 0.733 \\
\hline AGREE1 & 0.901 & & & OE1 & 0.877 & & \\
\hline AGREE2 & 0.828 & & & OE 2 & 0.871 & & \\
\hline AGREE 3 & 0.889 & & & OE 3 & 0.892 & & \\
\hline AGREE 4 & 0.806 & & & OE 4 & 0.882 & & \\
\hline Conscientiousness & & 0.936 & 0.746 & OE 5 & 0.753 & & \\
\hline CON1 & 0.888 & & & Risk Aversion & & 0.896 & 0.682 \\
\hline CON 2 & 0.874 & & & RA1 & 0.766 & & \\
\hline $\operatorname{coN} 3$ & 0.927 & & & RA 2 & 0.839 & & \\
\hline $\operatorname{CON} 4$ & 0.859 & & & RA 3 & 0.868 & & \\
\hline CON 5 & 0.761 & & & RA 4 & 0.829 & & \\
\hline \multicolumn{8}{|c|}{ Second-Order Measurement Model } \\
\hline \multicolumn{2}{|l|}{ Variables } & \multicolumn{2}{|c|}{ Loadings } & \multicolumn{2}{|l|}{ CR } & \multicolumn{2}{|c|}{ AVE } \\
\hline \multicolumn{2}{|l|}{ Investment Intention } & & & \multicolumn{2}{|l|}{0.714} & \multicolumn{2}{|c|}{0.555} \\
\hline LTI & & \multicolumn{2}{|c|}{0.743} & & & & \\
\hline \multicolumn{2}{|l|}{ STI } & \multicolumn{2}{|c|}{0.747} & & & & \\
\hline
\end{tabular}

The indicator reliability of each item is assessed by reviewing the outer loadings of every item of every construct (Duarte \& Raposo, 2010; Hair Jr et al., 2012, 2016; Hulland, 1999). The indicator reliability explains that each item is a good measurement of the latent construct. To retain individual items, a rule of thumb is provided by researchers that for retention, a loading between 0.40 to 0.70 is deemed acceptable (Hair Jr et al., 2016). Table 1 reports the outer loading for every latent variable which lies in the acceptable range and thus satisfies the criteria for retention as per the rule of thumb, implying that the criteria for individual item reliability are met. 
Composite Reliability (CR) is used as a widespread method for internal consistency assessment. Werts, Linn, and Joreskog (1974) developed CR, and CR is given preference over Cronbach's alpha because CR may result in a better estimate. A rule of thumb was determined for the interpretation of a coefficient's composite reliability where an upper cap of 0.7 or more was set as a benchmark (Bagozzi \& Yi, 1988; Hair Jr et al., 2011; Henseler et al., 2009). Table 1 exhibits the coefficient's CR for every latent variable used in the present empirical work, which lies between 0.816 to 0.936, implying that the values of the construct are higher than the cut-off of 0.70 . These measures exhibit satisfactory internal consistency reliability (Hair Jr et al., 2011).

The use of Average Variance Extracted (AVE) for assessing the convergent validity of every construct was suggested (Fornell \& Larcker, 1981). The value of AVE should be 0.50 or more to exhibit sufficient convergent validity (Chin, 1998; Henseler et al., 2009). The values of AVE (Table 1) indicate a value of 0.656 for long-term investment intention and 0.582 for short-term investment intention in the firstorder measurement model. The personality trait variables taken as predictors in the study, namely, openness to experience, conscientiousness, extraversion, agreeableness, and neuroticism have an AVE of 0.733, 0.746, 0.551, 0.734, and 0.599 respectively, whereas, risk aversion has an AVE of 0.682. In the second-order measurement model, the AVE of investment intention is 0.555 . The AVE values imply that the empirical work demonstrates a satisfactory convergent validity (Chin, 1998; Henseler et al., 2009).

Discriminant validity indicates that the two conceptually significant concepts used in the model are distinct (Joseph et al., 2010). Fornell's and Larcker's (1981) criteria were used in the current empirical work to assess discriminant validity. As a rule of thumb, the use of AVE with 0.5 value or higher is suggested as well as the square root of AVE must be greater than the correlations between latent variables. Table 1 indicates that the AVE of all constructs is more than the cut-off value of 0.50 , while Table 2 indicates the square root of AVE is greater than the correlations between variables, implying that the empirical work demonstrates satisfactory discriminant validity.

A new method of assessing discriminant validity, the Heterotrait-Monotrait (HTMT) ratio of correlations is proposed by Henseler, Ringle, and Sarstedt (2015) which is a multitrait-multimethod matrix. If the value of the HTMT ratio is higher than the threshold value, it shows a lack of discriminant validity. Gold, Malhotra, and Segars (2001) proposed a threshold value of 0.90 for the HTMT ratio. The values should be lower than 0.90 or it should not be close to 1. The lower the value, the higher is the discriminant validity. Table 5 summarizes the new criteria for assessing discriminant validity. The values indicate that the discriminant validity has no issues as the threshold value is less than 0.9 .

Table 2: Discriminant Validity

\begin{tabular}{|c|c|c|c|c|c|c|c|c|}
\hline \multicolumn{9}{|c|}{ Fornell and Larcker Criterion } \\
\hline & AGREE & ATR & CON & EXTRA & LTI & NEU & OE & STI \\
\hline AGREE & 0.857 & & & & & & & \\
\hline ATR & 0.357 & 0.826 & & & & & & \\
\hline CON & 0.182 & 0.508 & 0.864 & & & & & \\
\hline EXTRA & 0.087 & 0.285 & 0.251 & 0.742 & & & & \\
\hline LTI & 0.345 & 0.661 & 0.307 & 0.209 & 0.810 & & & \\
\hline NEU & -0.206 & -0.476 & -0.544 & -0.239 & -0.420 & 0.774 & & \\
\hline OE & 0.108 & 0.396 & 0.488 & 0.064 & 0.240 & -0.419 & 0.856 & \\
\hline STI & 0.214 & 0.453 & 0.415 & 0.301 & 0.110 & -0.331 & 0.353 & 0.763 \\
\hline \multicolumn{9}{|c|}{ Heterotrait-Monotrait Ratio of Correlations Criterion } \\
\hline \multicolumn{9}{|c|}{\begin{tabular}{l|l|l|l} 
AGREE & & & \\
\end{tabular}} \\
\hline ATR & 0.407 & & & & & & & \\
\hline CON & 0.197 & 0.578 & & & & & & \\
\hline EXTRA & 0.194 & 0.297 & 0.270 & & & & & \\
\hline LTI & 0.377 & 0.621 & 0.333 & 0.229 & & & & \\
\hline NEU & 0.232 & 0.566 & 0.621 & 0.256 & 0.489 & & & \\
\hline $\mathrm{OE}$ & 0.120 & 0.449 & 0.533 & 0.119 & 0.259 & 0.476 & & \\
\hline STI & 0.245 & 0.525 & 0.470 & 0.321 & 0.138 & 0.392 & 0.402 & \\
\hline
\end{tabular}




\subsubsection{Structural Model}

The current empirical research applied the standard bootstrapping procedure (500 bootstraps samples) and 397 respondents to assess the statistical significance of path coefficients (Hair Jr et al., 2011, 2012, 2016; Henseler et al., 2009). Table 3 reveals the complete structural model estimates of the current study.

Hypothesis $1\left(H_{1}\right)$ is formulated to test the relationship between extraversion and investment intention; it is a one-tail hypothesis and a positive relationship is hypothesized. The results shown in Table 3 indicate a significant positive relationship between extraversion and the investment intention of an individual investor $\left(\beta_{1}=\right.$ $0.151 ; p$-value $=.000)$ at a $1 \%$ percent level implying that $H_{1}$ is supported.

Hypothesis $2\left(\mathrm{H}_{2}\right)$ is formulated to test the relationship between openness to experience and investment intention; it is a one-tail hypothesis and a positive relationship is hypothesized. The results shown in Table 3 indicate a significant positive relationship between openness to experience and the investment intention of an individual investor $\left(\beta_{2}=0.105 ; p\right.$-value $\left.=.007\right)$ at a $1 \%$ percent level implying that $H_{2}$ is supported.

Hypothesis $3\left(H_{3}\right)$ is formulated to test the relationship between agreeableness and investment intention of an individual investor; it is a one-tail hypothesis and a positive relationship is hypothesized. The results are shown in Table 3 confirm a positive relationship between agreeableness and the investment intention of an individual investor $\left(\beta_{3}=\right.$ $0.162 ; p$-value $=.000)$ at a $1 \%$ percent level implying that $\mathrm{H}_{3}$ is supported.

Hypothesis $4\left(\mathrm{H}_{4}\right)$ is formulated to test the relationship between conscientiousness and investment intention; it is a one-tail hypothesis and a positive relationship is hypothesized. The results are shown in Table 3 confirm a positive relationship between conscientiousness and the investment intention of an individual investor $\left(\beta_{4}=0.066\right.$; $p$-value $=.093)$ at a $10 \%$ percent level implying that $H_{4}$ is supported.
Hypothesis $5\left(H_{5}\right)$ is formulated to test the relationship between neuroticism and investment intention; it is a onetail hypothesis and a negative relationship is hypothesized. The results shown in Table 3 indicate a negative relationship between neuroticism and the investment intention of an individual investor $\left(\beta_{5}=-0.162 ; p\right.$-value $\left.=.000\right)$ at a $1 \%$ percent level implying that $H_{5}$ is supported.

Hypothesis $6\left(\mathrm{H}_{6}\right)$ is formulated as a two-tailed hypothesis to test the relationship between risk aversion and investment intention. The results shown in Table 3 indicate that there is a positive relationship between risk aversion and the investment intention of an individual investor $\left(\beta_{6}=0.408 ; p\right.$-value $\left.=.000\right)$.

Several researchers have explained the variance in the model by using the value of R-Square (Elliott \& Woodward, 2007; Hair Jr et al., 2010, 2006). $\mathrm{R}^{2}$ is a statistical measure that represents the proportion of the variance for a dependent variable that's explained by the independent variables in the current empirical work.

The coefficient of determination, $R^{2}$ is shown in Table 4. The $\mathrm{R}^{2}$ of 0.539 indicates that the independent variables altogether explain about $54 \%$ of the variance in the dependent variable (investment intention of individual investors). The $\mathrm{R}^{2}$ value is moderate in the current study (Chin, 2010).

Q-square $\left(\mathrm{Q}^{2}\right)$ is an indicator of the model's predictive relevance known as the criterion of predictive accuracy. It is also known as Stone-Geisser's Q2 (Geisser, 1974; Stone, 1974). If the value of $Q^{2}$ is less than 0 , it indicates that the model is not a good fit and all independent variables cannot explain the dependent variable, hence providing no predictive relevance among exogenous and endogenous variables (Hair Jr et al., 2016; Henseler et al., 2009). Table 4 indicates that the value $\mathrm{Q}^{2}=0.283$ is greater than 0 and is a good indicator of predictive relevance in this study.

Table 4: Construct Cross-Validated Redundancy

\begin{tabular}{|l|c|c|}
\hline & $\begin{array}{c}\mathbf{R}-\mathbf{S} q u a r e \\
\left(\mathbf{R}^{2}\right)\end{array}$ & Q-Square $\left(\mathbf{Q}^{2}\right)$ \\
\hline Investment Intention & 0.539 & 0.283 \\
\hline
\end{tabular}

Table 3: Structural Model

\begin{tabular}{|l|l|c|c|c|c|c|c|}
\hline Hypothesis & \multicolumn{1}{|c|}{ Relationship } & $\boldsymbol{\beta}$ & S.E. & $\boldsymbol{t}$-value & $\boldsymbol{p}$-value & Decision & $\boldsymbol{f}$-square \\
\hline 1 & Extraversion $\rightarrow$ Investment Intention & 0.151 & 0.039 & 3.859 & 0.000 & Supported & 0.073 \\
\hline 2 & $\begin{array}{l}\text { Openness to Experience } \rightarrow \text { Investment } \\
\text { Intention }\end{array}$ & 0.105 & 0.043 & 2.451 & 0.007 & Supported & 0.039 \\
\hline 3 & Agreeableness $\rightarrow$ Investment Intention & 0.162 & 0.040 & 4.046 & 0.000 & Supported & 0.112 \\
\hline 4 & $\begin{array}{l}\text { Conscientiousness } \rightarrow \text { Investment } \\
\text { Intention }\end{array}$ & 0.066 & 0.050 & 1.323 & 0.093 & Supported & 0.073 \\
\hline 5 & Neuroticism $\rightarrow$ Investment Intention & -0.162 & 0.049 & 3.325 & 0.000 & Supported & 0.064 \\
\hline 6 & Risk Aversion $\rightarrow$ Investment Intention & 0.408 & 0.057 & 7.124 & 0.000 & Supported & 0.214 \\
\hline
\end{tabular}




\subsection{Discussion}

According to McCrae and Costa Jr (1997), an extravert is defined as an individual who is active, optimistic, excitement seeking, and socializes in big crowds. The results of this study found a positive relationship between extraversion and investment intention which supports the conclusions given by Pan and Statman (2013). Extraversion often creates a trade-off and tends to capitalize on the money more in the stock market. As defined by Martins (2002), individuals with an attribute of openness to experience are broad-minded, resourceful, and creative. They have an appeal towards new thoughts, aesthetics, and novelty (Gunkel et al., 2010). The results of this study confirm a significant positive association between openness to experience and investment intention and the results are consistent with that of Mayfield et al. (2008) who found a positive relationship between openness to experience and investment intention.

Agreeable persons tend to avoid conflicts and positively consider the information provided by others without any critical assessment (McCrae \& Costa Jr, 1997). The results of this study confirm a positive relationship between agreeableness and investment intention. Gunkel et al. (2010) stated that "conscientious individuals are actively involved in decision making". Conscientious investors avoid depending on misconceptions and this ability makes them more particular about the choice of investment and risk tolerance (Sadi et al., 2011). The results of this study confirm a positive association between conscientiousness and investment intention.

Neurotic investors avoid indecision, are hostile towards risk, and avoid debt securities and foreign equities (Niszczota, 2014). Moreover, neurotic people lack conceptual understanding, analytical ability, cognitive skills, and critical thinking. These shortcomings make neurotic individuals anxious and afraid while taking risky decisions (McCrae \& Costa Jr, 1997; Young et al., 2012). Pak \& Mahmood (2015) have stated that neuroticism has a negative relation to risky behavior. The results confirm a negative relationship between neuroticism and investment intention as hypothesized. Finally, the present study found a positive relationship of risk aversion and investment intention of individual investors which is contradictory to the findings of Mayfield et al. (2008) who found a negative connection between risk aversion and investment intention.

\section{Conclusions and Recommendations}

With limited investment opportunities, investors in Balochistan are more inclined to invest in real estate, agricultural extension, and livestock management. Globalization has increased the resources families hold and increased investment prospects in terms of their investment horizon and varying behavior to foresee risk and return (Pellinen et al., 2011). This study reveals that personality traits lead the way for a specific individual's preference concerning their investment choice. According to Keil, Depledge, and Rai (2007), investors most of the time while dealing with uncertainty and ambiguity count on their cognitive inclinations in the time of taking their financial decisions.

This empirical work aims to test the relationship of personality traits and risk attitude with investment intention of investors in Balochistan by applying the PLS path modeling technique which is widely acknowledged and applied in the study of social sciences (Hair Jr et al., 2011, 2012; Kura, 2016; Kura et al., 2015; Roldan \& SanchezFranco, 2012) and is the pioneer study in Balochistan to explore the determinants significant in an investor's investment intention.

The current research tested 6 hypotheses derived from the five-factor theory and risk attitude, and all the alternative hypotheses were accepted in the study. The findings indicate that all the predictors taken in the study are statistically significant with investors' investment intention with risk aversion as the strongest predictor. Openness to experience, extraversion, consciousness, agreeableness, and risk aversion have a positive significant relationship with an individual's investment intention, while neuroticism has a negative relationship with an investor's investment intention.

\subsection{Future Research and Policy Implications}

It is suggested that studies in the future may focus on the entire country by assessing the similarities and differences among investors of Pakistan based on their cultural differences and the availability of diverse investment alternatives. Future research may also be based on the youth of Balochistan (Generation Y) as they make most of the total population of Pakistan. Additionally, the investment behavior of retired individuals can be evaluated by extending the present study with a diverse sampling frame.

The results of the present study will help financial planners to make available diverse investment alternatives for investors in Balochistan, thus catering to their unique needs. Academia must offer courses on contemporary finance paradigm based on behavioral finance to enable future business graduates to make wise financial decisions.

\section{References}

Allport, G. W. (1937). Personality: A psychological interpretation. Oxford, England: Holt.

Bagozzi, R. P., \& Yi, Y. (1988). On the evaluation of structural equation models. Journal of the Academy of Marketing Science, 16(1), 74-94. doi: https://doi.org/10.1007/BF02723327 
Bozionelos, N. (2004). The big five personalities and work involvement. Journal of Managerial Psychology, 19(1), 69-81. doi: https://doi.org/10.1108/02683940410520664

Brown, S., \& Taylor, K. (2014). Household finances and the 'Big Five'personality traits. Journal of Economic Psychology, 45, 197-212. doi: https://doi.org/10.1016/j.joep.2014.10.006

Busato, V. V., Prins, F. J., Elshout, J. J., \& Hamaker, C. (1998). The relation between learning styles, the Big Five personality traits, and achievement motivation in higher education. Personality and Individual Differences, 26(1), 129-140. doi: https://doi. org/10.1016/S0191-8869(98)00112-3

Cattell, R. B. (1943). The description of personality: I. Foundations of trait measurement. Psychological Review, 50(6), 559-594. doi: https://doi.org/10.1037/h0057276

Chin, W. W. (1998). The partial least squares approach to structural equation modeling. In: G. A. Marcoulides (Ed.), Modern methods for business research (pp. 295-336). Mahwah, NJ: Lawrence Erlbaum Associates.

Chin, W. W. (2010). How to write up and report PLS analyses In: Handbook of partial least squares (pp. 655-690). New York, NY: Springer.

Corter, J. E., \& Chen, Y.-J. (2006). Do investment risk tolerance attitudes predict portfolio risk? Journal of Business and Psychology, 20(3), 369-381. doi: 10.1007/s10869-005-9010-5

Costa Jr, P. T., \& McCrae, R. R. (1992). Four ways five factors are basic. Personality and Individual Differences, 13(6), 653-665. doi: https://doi.org/10.1016/0191-8869(92)90236-I

Costa, P. T., McCrae, R. R., \& Holland, J. L. (1984). Personality and vocational interests in an adult sample. Journal of Applied Psychology, 69(3), 390-400. doi: https://doi.org/10.1037/00219010.69.3.390

Crysel, L. C., Crosier, B. S., \& Webster, G. D. (2013). The "Dark Triad" and risk behavior. Personality and Individual Differences, 54(1), 35-40. doi: https://doi.org/10.1016/j. paid.2012.07.029

DeBondt, W., Forbes, W., Hamalainen, P., \& Gulnur Muradoglu, Y. (2010). What can behavioral finance teach us about finance? Qualitative Research in Financial Markets, 2(1), 29-36. doi: https://doi.org/10.1108/17554171011042371

Diacon, S. (2004). Investment risk perceptions: Do consumers and advisers agree? International Journal of Bank Marketing, 22(3), 180-199. doi: https://doi.org/10.1108/02652320410530304

Digman, J. M. (1990). Personality structure: Emergence of the fivefactor model. Annual Review of Psychology, 41(1), 417-440. doi: https://doi.org/10.1146/annurev.ps.41.020190.002221

Dolan, P., Elliott, A., Metcalfe, R., \& Vlaev, I. (2012). Influencing financial behavior: From changing minds to changing contexts. Journal of Behavioral Finance, 13(2), 126-142. doi: https://doi. org/10.1080/15427560.2012.680995

Duarte, P. A. O., \& Raposo, M. L. B. (2010). A PLS model to study brand preference: An application to the mobile phone market. Handbook of partial least squares (pp. 449-485): Springer.
Durand, R., Newby, R., Tant, K., \& Trepongkaruna, S. (2013). Overconfidence, overreaction, and personality. Review of Behavioral Finance, 5(2), 104-133. doi: https://doi.org/10.1108/ RBF-07-2012-0011

Durand, R. B., Newby, R., \& Sanghani, J. (2008). An intimate portrait of the individual investor. The Journal of Behavioral Finance, 9(4), 193-208. doi: https://doi. org/10.1080/15427560802341020

Elliott, A. C., \& Woodward, W. A. (2007). Statistical analysis quick reference guidebook: With SPSS examples. Thousand Oaks, CA: Sage Publications.

Erdfelder, E., Faul, F., \& Buchner, A. (1996). GPOWER: A general power analysis program. Behavior Research Methods, Instruments, \& Computers, 28(1), 1-11. doi: https://link. springer.com/content/pdf/10.3758/BF03203630.pdf

Erdheim, J., Wang, M., \& Zickar, M. J. (2006). Linking the Big Five personality constructs to organizational commitment. Personality and Individual Differences, 41(5), 959-970. doi: https://doi.org/10.1016/j.paid.2006.04.005

Fellner, G., \& Maciejovsky, B. (2007). Risk attitude and market behavior: Evidence from experimental asset markets. Journal of Economic Psychology, 28(3), 338-350. doi: https://doi. org/10.1016/j.joep.2007.01.006

Field, A. (2009). Discovering statistics using SPSS. Thousand Oaks, CA: Sage Publications.

Fiske, D. W. (1949). Consistency of the factorial structures of personality ratings from different sources. The Journal of Abnormal and Social Psychology, 44(3), 329-344. doi: https:// doi.org/10.1037/h0057198

Fornell, C., \& Larcker, D. F. (1981). Structural equation models with unobservable variables and measurement error: Algebra and statistics. Journal of Marketing Research, 18(3), 382-388. doi: https://doi.org/10.1177/002224378101800313

Gambetti, E., \& Giusberti, F. (2012). The effect of anger and anxiety traits on investment decisions. Journal of Economic Psychology, 33(6), 1059-1069. doi: https://doi.org/10.1016/j. joep.2012.07.001

Geisser, S. (1974). A predictive approach to the random effect model. Biometrika, 61(1), 101-107. doi: https://doi.org/10.1093/ biomet/61.1.101

Gold, A. H., Malhotra, A., \& Segars, A. H. (2001). Knowledge management: An organizational capabilities perspective. Journal of Management Information Systems, 18(1), 185-214. doi: https://doi.org/10.1080/07421222.2001.11045669

Grable, J. E., \& Lytton, R. H. (2003). The development of a risk assessment instrument: A follow-up study. Financial Services Review, 12(3), 257-274.

Gunkel, M., Schlaegel, C., Langella, I. M., \& Peluchette, J. V. (2010). Personality and career decisiveness: An international empirical comparison of business students' career planning. Personnel Review, 39(4), 503-524. doi: https://doi. org/10.1108/00483481011045443 
Hair Jr, J. F., Black, W. C., Babin, B. J., \& Anderson, R. E. (2010). Multivariate data analysis: Global edition. Upper Saddle River, NJ: Pearson Higher Education

Hair Jr, J. F., Ringle, C. M., \& Sarstedt, M. (2011). PLS-SEM: Indeed a silver bullet. Journal of Marketing Theory and Practice, 19(2), 139-152. doi: https://doi.org/10.2753/ MTP1069-6679190202

Hair Jr, J. F., Sarstedt, M., Pieper, T. M., \& Ringle, C. M. (2012). The use of partial least squares structural equation modeling in strategic management research: A review of past practices and recommendations for future applications. Long-Range Planning, 45(5-6), 320-340. doi: https://doi.org/10.1016/j. lrp.2012.09.008

Hair Jr, J. F., Sarstedt, M., Ringle, C. M., \& Mena, J. A. (2012). An assessment of the use of partial least squares structural equation modeling in marketing research. Journal of the Academy of Marketing Science, 40(3), 414-433. doi: https:// doi.org/10.1007/s11747-011-0261-6

Hair Jr, J. F., Black, W., Babin, B., Anderson, R., \& Tatham, R. (2006). Multivariate Data Analysis (6th ed.). Upper Saddle River, NJ: Pearson Prentice Hall.

Hair Jr, J. F., Hult, G. T. M., Ringle, C., \& Sarstedt, M. (2016). A primer on partial least squares structural equation modeling (PLS-SEM). Thousand Oaks, CA: Sage Publications.

Han, J. H. (2020). The effects of personality traits on subjective well-being and behavioral intention associated with serious leisure experiences. Journal of Asian Finance, Economics, and Business, 7(5), 167-176. https://doi.org/10.13106/jafeb.2020. vol7.no5.167

Henseler, J., Ringle, C. M., \& Sarstedt, M. (2015). A new criterion for assessing discriminant validity in variance-based structural equation modeling. Journal of the academy of marketing science, 43, 115-135. doi: https://doi.org/10.1007/s11747-0140403-8

Henseler, J., Ringle, C. M., \& Sinkovics, R. R. (2009). The use of partial least squares path modeling in international marketing. In: R. R. Sinkovics, \& P. N. Ghauri (Eds.), New challenges to international marketing (pp. 277-319). Bingley, UK: Emerald Group Publishing Limited.

Hulland, J. (1999). Use of partial least squares (PLS) in strategic management research: A review of four recent studies. Strategic Management Journal, 20(2), 195-204. doi: https:// doi.org/10.1002/(SICI)1097-0266(199902)20:2<195::AID$\mathrm{SMJ} 13>3.0 . \mathrm{CO} ; 2-7$

Hunter, K., \& Kemp, S. (2004). The personality of e-commerce investors. Journal of Economic Psychology, 25(4), 529-537. doi: https://doi.org/10.1016/S0167-4870(03)00050-3

Joseph, F., Hair Jr, J. F., Black, W., Babin, B., \& Anderson, R. (2010). Multivariate data analysis: a global perspective (7th ed.). Upper Saddle River, NJ: Prentice-Hall.

Keil, M., Depledge, G., \& Rai, A. (2007). Escalation: The role of problem recognition and cognitive bias. Decision Sciences, 38(3), 391-421. doi: https://doi.org/10.1111/j.15405915.2007.00164.x
Kiev, A. (2003). The psychology of risk: Mastering market uncertainty. Hoboken, NJ: John Wiley \& Sons.

Komarraju, M., \& Karau, S. J. (2005). The relationship between the big five personality traits and academic motivation. Personality and Individual Differences, 39(3), 557-567. doi: https://doi. org/10.1016/j.paid.2005.02.013

Kura, K. M. (2016). Linking environmentally specific transformational leadership and environmental concern to green behavior at work. Global Business Review, 17(3), 1S-14S. doi: https://doi.org/10.1177/0972150916631069

Kura, K. M., Shamsudin, F. M., \& Chauhan, A. (2015). Does selfregulatory efficacy matter? Effects of punishment certainty and punishment severity on organizational deviance. SAGE Open, 5(2), 1-14. doi: https://doi.org/10.1177/2158244015591822

Leary, M. M., Reilly, M. D., \& Brown, F. W. (2009). A study of personality preferences and emotional intelligence. Leadership \& Organization Development Journal, 30(5), 421-434. doi: https://doi.org/10.1108/01437730910968697

Martins, N. (2002). A model for managing the trust. International Journal of Manpower, 23(8), 754-769. doi: https://doi. org/10.1108/01437720210453984

Mayfield, C., Perdue, G., \& Wooten, K. (2008). Investment management and personality type. Financial Services Review, 17(3), 219-236.

McCrae, R. R., \& Costa Jr, P. T. (1997). Personality trait structure as a human universal. American Psychologist, 52(5), 509-516. doi: https://doi.org/10.1037/0003-066X.52.5.509

McCrae, R. R., \& Costa, P. T. (1987). Validation of the five-factor model of personality across instruments and observers. Journal of Personality and Social Psychology, 52(1), 81-90. doi: https:// doi.org/10.1037/0022-3514.52.1.81

Muris, P. (2006). Maladaptive schemas in non-clinical adolescents: Relations to perceived parental rearing behaviors, big five personality factors, and psychopathological symptoms. Clinical Psychology \& Psychotherapy: An International Journal of Theory \& Practice, 13(6), 405-413. doi: https://doi. org/10.1002/cpp.506

Nandan, T., \& Saurabh, K. (2016). Big-five personality traits, financial risk attitude, and investment intentions: a study on Generation Y. International Journal of Business Forecasting and Marketing Intelligence, 2(2), 128-150. doi: https://doi. org/10.1504/IJBFMI.2016.078154

Nga, J. K., \& Ken Yien, L. (2013). The influence of personality traits and demographics on financial decision making among Generation Y. Young Consumers, 14(3), 230-243. doi: https:// doi.org/10.1108/YC-11-2012-00325

Nguyen, D. D., \& Nguyen, C. V. (2020). The impact of operating cash flow in the decision-making of individual investors in Vietnam's Stock Market. Journal of Asian Finance, Economics, and Business, 7(5), 19-29. https://doi.org/10.13106/jafeb.2020. vol7.no5.019

Nigg, J. T., John, O. P., Blaskey, L. G., Huang-Pollock, C. L., Willcutt, E. G., Hinshaw, S. P., \& Pennington, B. (2002). 
Big five dimensions and ADHD symptoms: Links between personality traits and clinical symptoms. Journal of Personality \& Social Psychology, 83(2), 451-469.

Niszczota, P. (2014). Neuroticism, uncertainty, and foreign investment. Retrieved from papers.ssrn.com: doi:https://dx.doi. org $/ 10.2139 / \mathrm{ssrn} .2431188$

Olsen, R. A., \& Cox, C. M. (2001). The influence of gender on the perception and response to investment risk: The case of professional investors. The Journal of Psychology and Financial Markets, 2(1), 29-36. doi: https://doi.org/10.1207/ S15327760JPFM0201_3

Pak, O., \& Mahmood, M. (2015). Impact of personality on risk tolerance and investment decisions: A study on potential investors of Kazakhstan. International Journal of Commerce and Management, 25(4), 370-384. doi: https://doi.org/10.1108/ IJCoMA-01-2013-0002

Pan, C. H., \& Statman, M. (2013). Investor personality in investor questionnaires. Journal of Investment Consulting, 14(1), 48-56.

Pellinen, A., Tormakangas, K., Uusitalo, O., \& Raijas, A. (2011). Measuring the financial capability of investors: A case of the customers of mutual funds in Finland. International Journal of Bank Marketing, 29(2), 107-133. doi: https://doi. org/10.1108/02652321111107611

Riley, P. J., \& Kiger, G. (2002). Increasing survey response: The drop-off/pick-up technique. The Rural Sociologist, 22(1), 6-9.

Ringle, C. M., Wende, S., \& Becker, J.M. (2015). SmartPLS 3. Scientific Research, 15, 1-5.

Roldán, J. L., \& Sanchez-Franco, M. J. (2012). Variance-based structural equation modeling: Guidelines for using partial least squares in information systems research. In: M. Mora, O. Gelman, A. Steenkamp, \& M. Raisinghani, Research methodologies, innovations, and philosophies in software systems engineering and information systems (pp. 193-221). Pennsylvania, USA: IGI Global.

Sadi, R., Asl, H. G., Rostami, M. R., Gholipour, A., \& Gholipour, F. (2011). Behavioral finance: the explanation of investors' personality and perceptual biases effects on financial decisions. International Journal of Economics and Finance, 3(5), 234241. doi: 10.5539/ijef.v3n5p234

Sarstedt, M., Hair Jr, J. F., Cheah, J.H., Becker, J. M., \& Ringle, C. M. (2019). How to specify, estimate, and validate higher-order constructs in PLS-SEM. Australasian Marketing Journal, 27(3), 197-211. doi: https://doi.org/10.1016/j.ausmj.2019.05.003

Scott, B. A., \& Colquitt, J. A. (2007). Are organizational justice effects bounded by individual differences? An examination of equity sensitivity, exchange ideology, and the Big Five. Group \& Organization Management, 32(3), 290-325. doi: https://doi. org/10.1177/1059601106286877

Shiller, R. J. (2002). Bubbles, human judgment, and expert opinion. Financial Analysts Journal, 58(3), 18-26. doi: https://doi. org/10.2469/faj.v58.n3.2535

Smith, A. L., \& Harvey, T. W. (2011). Test of a theory: An empirical examination of the changing nature of investor behavior. Journal of Management Policy and Practice, 12(3), 49-68.

Stone, M. (1974). Cross-validation and multinomial prediction. Biometrika, 61(3), 509-515. doi: https://doi.org/10.1093/ biomet/61.3.509

Tang, T. L.P. (2007). Income and quality of life: Does the love of money make a difference? Journal of Business Ethics, 72, 375-393. doi: https://doi.org/10.1007/s10551-006-9176-4

Udin, U., \& Yuniawan, A. (2020). Psychological capital, personality traits of big-five, organizational citizenship behavior, and task performance: Testing their relationships. Journal of Asian Finance, Economics, and Business, 7(9), 781-790. https://doi. org/10.13106/jafeb.2020.vol7.no9.781

Vorkapić, S. T. (2012). The significance of preschool teacher's personality in early childhood education: Analysis of Eysenck's and Big Five dimensions of personality. International Journal of Psychology and Behavioral Sciences, 2(2), 28-37. doi: 10.5923/j.ijpbs.20120202.05

Werts, C. E., Linn, R. L., \& Jöreskog, K. G. (1974). Intraclass reliability estimates: Testing structural assumptions. Educational and Psychological Measurement, 34(1), 25-33. doi: https://doi.org/10.1177/001316447403400104

Wood, R., \& Zaichkowsky, J. L. (2004). Attitudes and trading behavior of stock market investors: A segmentation approach. The Journal of Behavioral Finance, 5(3), 170-179. doi: https:// doi.org/10.1207/s15427579jpfm0503_5

Young, S., Gudjonsson, G. H., Carter, P., Terry, R., \& Morris, R. (2012). Simulation of risk-taking and its relationship with personality. Personality and Individual Differences, 53(3), 294-299. doi: https://doi.org/10.1016/j.paid.2012.03.014 